\title{
EFFECT OF ISLAMIC WORK ETHICS ON JOB PERFORMANCE: MEDIATING ROLE OF INTRINSIC MOTIVATION
}

\author{
Maaz Ud Din ${ }^{1 *}$, Faisal Khan ${ }^{2}$, Usman Khan ${ }^{3}$, Ana Kadarningsih ${ }^{4}$, Sih Darmi Astuti ${ }^{5}$ \\ *Corresponding Author: \\ ${ }^{1 \& 2}$ Department of Management Sciences, University of Swabi, KP-Pakistan, maazyousafzai12@gmail.com \\ ${ }^{3}$ Department of Tourism \& Hotel Management, University of Swabi, KP-Pakistan \\ ${ }^{4 \& 5}$ University of Dian Nuswantoro, Semarang, Indonesia
}

\begin{abstract}
The determination of this research is to examine the effect of Islamic work ethics on job performance and intrinsic motivation. This study also try to investigate the mediating role of intrinsic motivation on the association between Islamic Work Ethics and job performance. Nonprobability sampling, method was used. Data were collected through adopted questionnaires from 310 teachers of different Universities situated in Malakand Division, KP-Pakistan. SPSS and AMOS were used for Statistical tests. Empirical results indicate that there is a significant positive association between Islamic work ethics, Job performance and intrinsic motivation. The study determined that the idea of Islamic work ethics works as a therapy for the emergent ethical crisis of education sector of Pakistan which should be pervaded in organizational culture for sustainable job performance and growth. Further, study explain that intrinsic motivation mediates the association between Islamic Work Ethics and Job Performance. Implications and upcomingstudy recommendations are discuss in the conclusion.
\end{abstract}

Keywords : Islamic work ethics, intrinsic motivation, job performance, mediation, Pakistan.

\section{INTRODUCTION}

Islamic work ethics establishes Islam's expectations with admiration to behavior of individual at work place which comprises his or her exertion, responsibility dedication, social relations creativity and cooperation. Fundamentally, when someone has a strong association with God, one's attitudes and behaviors would tend to be reliable with the rubrics and circumstances of the religion (toward financial and non-financial rewards, and the ambition for upward career mobility (Rahman et al., 2006). Contrary work ethic, in specific, is supposed to replicate someone attitude towards numerous features of work, containing preference for activity and participation, approaches Yousef, 2001). Furthermore, the difference between ethics and IWE may be exemplified by the theory developed by Rawwas and Sidani (2013). In order to make an ethical decision, the main three factors come to our mind: organizational relationships, moral philosophies, and values. Protestant work ethics (PWE) was introduced by McClelland (1961) which is founded on the ideas in Christianity and rules.Simon (2008), argued that Islam and Christianity both are unlike in beliefs because Islam is completely based on Quran and Hadith but Christianity is purely based on the adapted Bible. Therefore, (Rokhman, 2010) argue, PWE is not applicable and effective in Islamic civilizations. Yousef (2001) and Ali (1988) also recommended thatIWE is one of the emerging area in Islamic world. Afterward, several Muslim scholars tries to investigate on IWE because Islam has its own social, economic and political system.

All systems that dealing with moral issues covers a perfect emphasis on invoking goodness tothe conduct and evading immoral conduct (Mohammad and Quoquab, 2016). Different Studies found on IWE that has significant effect on different outcomes which contain 
employees' wellbeing, organizational citizenship behavior, job satisfaction, job involvement intention to leave and organizational change (MaazUd Din and Farooq 2017; Ahmad, 2011; Khalil \& Abu-Saad, 2009; Khan et al., 2015; Mohamed, Karim, \& Hussein, 2010; Murtaza et al., 2014; Yousef, 2000a, 2001).

Salahudin et al., (2016) IWE is aninclusive, and moderate and quoted four issues from literature that the holy Prophet (PBUH) had stressed work as: 1- if not performed with highest ability is a not sanction, 2 - highest type worship, 3 , community should also get reasonable living standards and wealth from carrying on business, 4 - must also be in others' benefit like peace of social dimension.IWE bring moderation which means moderate work thinking in work ethics, in contrast of ultra-idealists thinking human beings, like angels and ultra-realist observing human beings as animals.

\section{Gap of the Study:}

Pakistan is largest Islamic country, located at a very imperative geographic position of the Muslims domain. Most of the researches conducted in telecom, banking and health sector but study on IWE are inadequate especially in Higher education sector. The most essential motive for conducting this study is to focus the relationships between IWE, job performance in respect of Universities in Malakand Division, KP-Pakistan. This study also inspectsthe mediating role of IM in the association between IWE andjob performance. If personnel are gratified withtheir work it will improve the performance of employeesalong with organizational performance having important effects on theorganization. Based on literature, this relationship hasnot yet been investigated in the prevalent conditions and less studies has been conducted. This study will fill the gapparticularly in the circumstance of Pakistan.

\section{LITERATURE REVIEW \\ Islamic Work Ethics (IWE)}

Islamic Work Ethics word has been drawn from Webber's theory of protestant work ethics (AjmalandIrfan, 2014). The Divine bases of Quran and Sunnah direct the best of morals insocioeconomic life. "You are the best of peoples, forbidding what is wrong, enjoining what is right, and believing inALLAH" evolved for mankind, (Quran.3:110). "And let there be from you a group welcoming toall to that is better (khair), enjoining what is right (marüf) and avoiding what is immoral (munkar)" (Qurān 3:104).IWE is the base that determines the engagement and participation of the worshippers in the place of work (Ali and Al-Owaihan, 2008). IWE upsurges in an employee intrinsic motivation to job and consequently he feels happiness in his work and is extremely satisfy with his job. IWE incorporate social connections between the organization and groups in the light of the Islamic guideline of work setting (Rahman et al., 2006).

The researchers have studied the various cultural environments in IWE during past two decades. The association of work ethics with intrinsic motivation, Turnover intention, job performance and further related organizationvariables have got enormous consideration in the literature (for example:Hayati,K. 2012,Durrani, F.2017; Zahrah,N. 2016). According to Rizk (2008), IWE is an orientation towards work and approaches work as a virtue in human'slives. 
IWE is actually based on the Qur'an and the teachings of the Prophet Muhammad (PBUH) who signified that hard work caused sins to be pardoned and the bequest of the four Caliphs of Islam (Ali, 2005; Rizk, 2008). Muslim researchers also identify the importance of IWE in the modern era, as it became part of Islamic thoughts which is valuable to everyone in the society. Ali \& Al-Owaihan (2008), categorized the work that is connectedwith Prophet Mohammad (PBUH) sayings into eleven branches that are the quality of work, significance of earning wealth, self-dependence wages, deeds and intentions bribery, practicing lawful business, monopoly, greed, transparency and kindness. They argued that Holy Prophet Mohammad (PBUH) clearly explain that to his followers that better work in society is that which give benefit to peoples. The Prophet SWA also specified that "Worshiping have seventy tracks, and the good one is the participation infairly earned living". Meaning that, work is the best method of worshiping. The Prophet Muhammad (PBUH) indorsed thepeople and their work to the upper most level if their activities assistothers. He said: "'The finest work is the one that outcomes in benefit" and "The greatest of people are those who advantage others".

\section{Job Performance (JP)}

According to Jex, (2002) mostly JP mentions to how an individual can achieve his orher work. JP can be define as all the conducts that theemployee involve at their work. The effort in sustaining the excellence level of job performance have been broadly considered, either by organizations itself or researchers. Job performance increases by IWB (Gong, Huang, \&Farh, 2009; Gilson \& Ruddy, 2005; Janssen, 2000) though, investigate in adequate consideration on how IWB increases intrinsic motivation. Al-Khasawneh et al., (2015), explain that Allah (SWA) insisted in different verses of Holy Qurran the need and giving same wages and not to be biased, according to performance and quantity of work the employees should paid fair wages. (Al- Qur'an'Al-Imran' 3:57). The administration system of Islam is an expanding pasture in the field of management sciences, (Armstrong, 2000), and by adopting ethical structure organization can improvetheir performance and work more efficiently (Abdi et al., 2014). Employees for any organization are the most essential assets and their conduct not only effects themselves but also affects the job performance as well as organizational performance, Aslam (2012).

\section{Intrinsic Motivation (IM)}

Intrinsic motivation refers to feelings of pleasure and satisfaction from performing the behavior (Vallerand, 1997).IM inspires optimal functioning and optimistic states by declining depression and anxiety (Kasser and Ryan, 1996). Thus, indorsing IM at work can make positive affective states among teachers which will slope them to develop better relationship with students (William, and Dale, 1998; Isen, 2001). IM also leads to good mental happiness which in turn can better teachers' interpersonal relations and self-esteem between teachers and students (Kasser and Ryan, 1996).Factors that have the potential to effect job motivation intrinsically consist of ability achievement, creativity utilization, relationship between coworkers, moral values, independence, recognition and job variety (Bono \& Judge, 2003; Argyris, 1973). The sole use of exterior motivating factors (financial rewards) has the tendency to crowd out intrinsic 
motivation (Frey \&Jegen, 2001). Intrinsic motivation inspires positive affective conditions and optimal functioning by reducing nervousness and depression (Kasser and Ryan, 1996).

\section{Islamic Work Ethics relationship with Job Performance}

The association between IWE and JP was investigated by Hayati and Caniago (2012) and correlation was found positive between them (i.e, $r=0.642, p<0.01$ ). Though, this research halso give the the oretical reasoning to clarify this association. Another study conducted by Abbasiand Muneer (2013), the IWE influence on JP by likening two unlike models of personality $\mathrm{X}$ and $\mathrm{Y}$. The affiliation between IWE and job performance was positive significant as the results of correlation analysis of this study suggested (i.e, $r=0.770, p<0.005$ ). Further regression analysis specified for personality $\mathrm{X}$ and $\mathrm{Y}$, there were $55 \%, 56 \%$ increases in JP because of IWE. They coped that IWE was a better predictor of JP for both personality X and personality Y. No more explanation was given to back consequences.

The study of Awan et al., (2014) shows that IWE have animportant positive link with $\mathrm{JP}(\mathrm{r}=0.34, \mathrm{p}<0.01)$. Data was gather from personnel employed in different government sector organization. Regression analysis of this study revealed that IWE significant effect and increase job performance of employee by $34 \%$.

IWE guideline in order to attain great goals and values ofjob performance in the domain of business. Organizational institutions for the corporate sector organization comprise the combination of IWE in corporate management to develop thejob as well asthe performance of organization to achieve sustainability along with the growing will andpotency to effect the management performance.

According to Armstrong (2000), Islamic management system is a growingmeadow and by accepting ethical structure organization can improvetheir performance and alsowork more efficiently (Abdi et al., 2014).

H1 : Islamic Work Ethics have positive significance effect on the Job Performance.

\section{Islamic Work Ethics and Intrinsic Motivation}

IWE is associated to essential job linked procedures and outcomes like motivation, organizational commitment, job performance and job satisfaction. (Roeand Ester, 1999; Berings et al., 2004). According to Ryan and Tipu (2016) values and work ethicssuch as multidimensional work morals can be main predictors in job inspiration. In a new research, they explain the association between ethics, return on investment and job satisfaction through theory of organizational justice influencing the employee'sopinion of equality, organizational efficiency and job orientation. From this viewpoint, personnel who observe their organization to be moral and following to the morals are more possible to feel their organization treat them justly. In return, this is likely to rise their level of job happiness and commitment, which, alongwith an optimistic behavior towards the job as well as organization, leads to effort towards the understandingof organizational objectives and a strong aspiration to retain with their organization (Rokhman, 2010). The study of Nithyanandan (2010), also indicated that a group having high level of Protestant work ethic (PWE) hadalso high level of IM. As, Hayati and 
Caniago (2012) also suggested, that the IWE had a meaning fully significant association with intrinsic motivation. Consequently, if employee treated the IWE with moreesteem, a higher level of intrinsic motivation can be expectable of them. In the study of Clary et al (1998), it was specified that IM had a well prognostic role in significant volunteer gratification. IM is followed by greater job gratification and a lesserneed to quit job, Pierce(1983).IWE is significantly related by intrinsic motivation. (i.e, $r=0.393, \mathrm{p}=0.01$ ), stated by (Zaman et al.,2013). The study also provide practical evidences that there is positive significant correlation between intrinsic motivation and IWE.

H2 : Islamic Work Ethics have positive significance effect on the Intrinsic Motivation.

\section{Intrinsic Motivation and Job performance}

Prior studies inspect IWE and its effect on commitment and job satisfaction (Rokhman\& Omar, 2008; Yousef, 2000, 2001). This study extended IWE by analysis its influence on JP, job satisfaction, intrinsic motivation and organizational commitment. IM has positive significant relationship with job satisfaction (Ahmed et al., 2010; Karatepe\&Tekinkus, 2006). Intrinsic motivation has significant influenceon organizational commitment (Mohsan et al., 2011; Karatepe \& Tekinkus, 2006). Similarly intrinsic motivation also affects the job performance (Oluseyi \& Ayo, 2009; Mundhra, 2010). Rokhman, Omar (2008) and Yousef (2001) investigate there is effect of the IWE on organizational commitment and job satisfaction affects organizational commitment similarly positive job performance also affects the job satisfaction (Shokrkon\&Naami, 2009; Ahmed et al., 2010). IWE enhance to higher performance spread the social welfare proposed by Ali and Al-Owaihan (2008).

H3 : Intrinsic Motivation have positive significance effect on Job performance.

\section{Mediating effect of Intrinsic Motivation}

Intrinsic motivation states to doing something because it is integrally enjoyable or interesting (Ryan and Deci, 2000). Previous study specifies that those employees who are more satisfied due to intrinsic motivation are more performance to their job. (Mundhra, 2010; Mohsan et al., 2011). Hayati and Caniago (2012) investigates that job satisfaction and intrinsic motivation moderate the association among IWE, JP and organizational commitment can be deliberated a maininfluence of their study. Further, their results show that the IWE better effect on intrinsic motivation and also pragmatic results of their research propose intrinsic motivation and job satisfaction moderates the association of the IWE on JP and organizational commitment. Another important study led by Sadozaiet al., (2013), between IWE and employee's Job satisfaction mediating role of intrinsic motivation. This study shows one mediating effect and three direct effects. Mediating variable indicates partial mediation and but the all direct effects have an important impact with each variable.

H4 : Intrinsic Motivation mediates the association between Islamic work ethics and Job Performance 


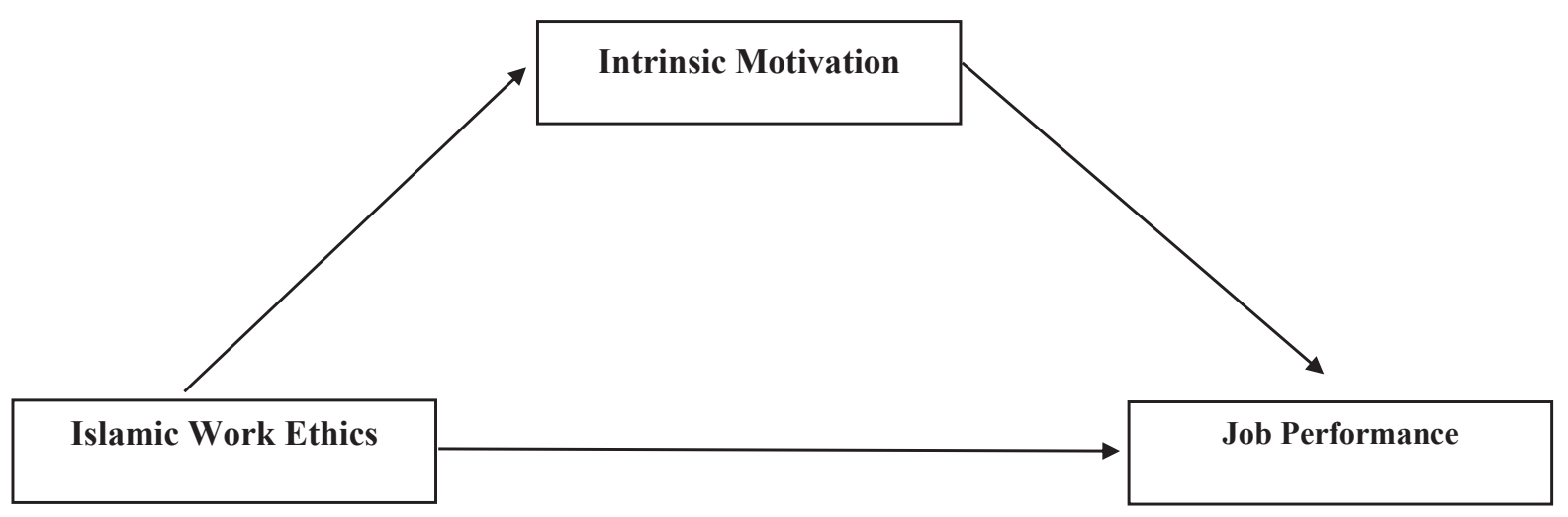

Conceptual model of the study

\section{RESEARCH METHODOLOGY}

Data was gather from 310, faculty members working in different universities situated in Malakand Division, KP-Pakistan through adopted questionnaires. Data was gather by using convenience sampling methodwhich is the most easiest and simple technique. IWE scales was used having17 items on 5-point likert scale which rang from strongly disagree to strongly agree and the scale was developed by Yousef (2000). The Cronabach's alpha of IWE items was 0.80. The IWE scale has also used by many research scholar like Rokhman, (2010); Yousef (2000); and Rehman, Fakhar, and Haroon, (2012). Intrinsic motivation scale was developed by Furnham (2005) having 6-item scale on 5-point likert scale. The Cronabach's alpha for the items of IMwas 0.84. Job performance item was developed by Goodman \& Svyantek (1999), which consists of 9 items scale on 5-point likert scale. The Cronabach's alphafor the items of JP was 0.76. Among different faculty members 390 questionnaires were distributed and 310 questionnaires were received. The male respondents were $180(58 \%)$ while female respondent were $130(41 \%)$.

In the age group, 36 respondents (11.6\%) were in category below 26 years, 186 respondents $(60 \%)$ were in $31-45$ years while 88 respondents $(28.38 \%)$ were in the age group of above 50 years. In education level, the graduate percentage and number of workers were 20 and 6.4 percent. The education level of respondents was Master is 204 (65.80\%), M.Phil. were 19(6.12\%) and Ph.D. was 87 (28.06 \%) respectively. SPSS and AMOS were used for statistical tests.

\section{RESULTS AND ANALYSIS}

Table 1. Correlation Matrix

Variables

Islamic Work Ethics

Job Performance

Intrinsic Motivation

\section{Islamic Work Ethics}

1

$0.36 * * *$

$0.48 * * *$
Job Performance

Intrinsic Motivation

$* * *$ Indicates significant association between variables at $\mathbf{p}<0.01$ level (2-tailed)

Table: 1 signifies correlation, all variables arepositively related with each other 
Table 2. Linear Regression (Direct Relationship)

Models

Model 1 Job Performance

Islamic Work Ethics

0.36

0.14

$\mathrm{R}^{2} \quad \mathrm{t}$-value

p-value F-value

Model 2 Intrinsic Motivation

Islamic Work Ethics

0.46

0.24

9.55

0.000

$19.17 * * *$

Model 3 Job Performance

Intrinsic Motivation

0.72

0.55

19.15

0.000

$366.41 * * *$

$* * *$ Indicates significant association between variables at $\mathbf{p}<0.01$ level (2-tailed)

Table 2, explain the direct relation between variables by testing regression analysis. The result of regression analysis is positive significance because p-value of regression coefficient $(\beta=0.36, p<0.001)$ which clarifies that when one unit rise in IWE, 0.36 unit will be increases in JP in higher education sector of Malakand Division.

Thecoefficientofdeterminationvalue $\left(\mathrm{R}^{2}=0.14\right)$ definesthat $14 \%$ variationsoccursbetween IWE and JP at workplace in universities ofMalakand Division. The t-value at $\mathrm{p}<0.001$ givesevidence thatthe association between IWE and Job performance (JP) at placeof work in the target population were positive significant .Hence, hypothesis-1 is accepted.

The association between IWE and IM is positive significant as the results of the study shown. Regression coefficient value $(\beta=\cdot, \Sigma 7, p<0.001)$ clarified that 0.46 , unit increasesin IM with one unitincrease in the IWE in universities of Malak and Division. The coefficient of determination value $\left(\mathrm{R}^{2}=0.24\right.$, ) showsthat $24 \%$ variation soccurs between IWE and IM at the work place in universities of Malak and Division. Hence, hypothesis-2 is accepted.

The consequences of this study more shown significant association between IM and JP. The regression coefficient value of this study explored strongly significant (i.e, $\beta=0.72$, $p$ $<0.001)$ which clarified that 0.72 unit increase in the IM with one unit increase in the JP in the universities of Malakand Division. The coefficient ofdetermination value $\left(\mathrm{R}^{2}=0.55\right)$ explain that 55\%variation present between IM and JP at work place. The outcomes of the research indicates, that the IM enhances JP. Hence, hypothesis-3 is accepted.

\section{Mediation Analysis}

Table 3, indicate the IM role as a mediator between IWE and JP. The method recommended by Barron \& Kenny (1986) to test this hypothesis. To test this hypothesis hierarchal regression analysis was used. In step-1 the direct relationship of IWE with JP was tested. In step-2 direct effect of IWE and IM was tested. In step-3 the directassociation between IM and JP were tested. In step 4 the relationships of IWE (Independent variable) with JS (dependent variable) through IM (Mediating variable) were tested. 
Table 3: Mediation Analysis

Variables

t-value

p-value

F-value

Step: 1 Job Performance

Islamic Work Ethics

0.36

$0.14 \quad-$

7.02

0.00

49.15***

Step: 2 Intrinsic Motivation

Islamic Work Ethics

0.46

0.24

9.55

0.00

19.17***

Step 3: Job Performance

Intrinsic Motivation

0.72

0.55

19.15

0.00

$366.41 * * *$

Step 4: Job Performance

Intrinsic Motivation

0.71

16.54

0.00

Islamic Work Ethics

0.02

0.55

0.40

0.56

0.59

$182.96 * * *$

$* * *$ shows association between variables at $\mathrm{p}<0.001$ level

\section{Mediation Role of IM in the relationship of IWE and JP}

Table3,explain the relationships between IWE and JP and intrinsic motivation as mediator. When chief effect of IWE wastested with Job performance, the results shows that IWE significantly predicted JP with $(\beta=0.36, p<0.01)$. The consequences shown that when mediating variable (IM) was come in into the equation the effect of IWE on JP was decreased to $(\beta=0.02, p<0.01)$.

Hence, in the existence of IM, IWE the value of regression coefficient with JP, IWE has becomes in significant (i.e, $\beta=0.02, p>0.05$ ) which shows partial mediation of IM. The strongly significant regression coefficient value (i.e, $\beta=0.72, p<0.01$ ) clarified that 0.72 unit improvement in the JP with one unit increase in the IM in the higher education sector of Malakand Division. Hence, hypothesis-4 is also accepted. The consequences of research shows that IWE improve the JP, provide information about the better work, behaviors and attitudes, as well as distinguish bad and good employees. IWE are totally based on the Holy Quran as well as Sunnah of the Prophet Muhammad (P.B.U.H). Thus, the hypothesis-4 is also confirm that the IM mediates the association between IWE and JP.

\section{CONCLUSION}

The key purpose of the study is to search IWE association to JP and IM. Results of the study suggest that an organizations can doefficiently its work by accepting a moral framework based on Islamic standards which guides and also helps the employees of the organization in undertaking their work appropriately. The results of the study arealign with previous results (e.gYousef, 2001; Nithyanandan, 2010; Othman et al., 2004; Rokhman and Omar. 2008; Ali \& Al-Owaihan, 2008; Grbac and Loncaric, 2009). This resultsshow thatthose employee who are more motivated intrinsically with their job are more gratified to their organization. Intrinsic motivation and job performance is significant and positiveand is harmonized with the results of prior researches (Ahmed et al, 2010; Shokrkon\&Naami, 2009). This results shows that those employee are more gratified with their job who are intrinsically motivated and they will perform their job efficiently. 
This Study suggest that the effects of IWE on the JP and IM is strongly significant. This study found numerous results that not only IWE directly affect the JP and IM but, also indirectly through the mediating effect of IM. This study fill the gap in Pakistani perspective particularly and must be cooperative for the manager of the organization who may construct and enhance their skills to assess employee's behavior that theyare satisfied and loyal with their job. If workers are gratified with their job, it will enhance the employees' performance along with an organizational performance with the having optimistic and momentous influence on the organization. IWE, JP and IM are important factors for organizations and without the presence of these factors organization may not be operate properly. The practical implication of this study can help to rise faithfulness with organization, by increasing their level of satisfaction about their job which eventually leads to less job stress, exhaustion and also lesser turnover intention.

\section{Limitations of Research}

The study has several limitations for the generalization of the out comes. The sample for the study was taken from the government sector universities only, while the sample with similar model from private sector universities may be gained to get credible results of the research. The sample size was consisted of 310 faculty members only working in higher education sector; though with large sample size, it can be protracted in the different fields like, health department, telecommunication area, banking sector, agriculture sector,services and manufacturing sector. To explore the effect IWE on the motivation, job stress, favoritism, job insecurity, turnover intentions and organizational politics through the organizational culture and Job Satisfaction, future studies may be conducted.

\section{REFERENCES}

Argyris, C. 1973. "Personality and Organization Theory Revisited. "Administrative Science Quarterly 18 (2): 141-167. doi:10.2307/2392060.

Aslam, R. (2012), "Investigating the relationship of OCB with job satisfaction organizational commitment and turnover intentions: A case study on teaching staff of University of the Punjab", International Journal of Economics and Management Sciences, 1 (9): 90 - 100.

Ahmed, M., Muddasar, M., \& Sir, S. (2012). The impact of work-family conflict and pay on employee job satisfaction with the moderating affect of perceived supervisor support in Pakistan banking sector. Global Journal of Management and Business Research, 12(6).

Abdi, M. F., Nor, S. F. D. M, \& Radzi, N. Z. M. (2014). The Impact of Islamic Work Ethics on Job Performance and Organizational Commitment. Proceedings of 5th Asia-Pacific Business Research Conference, Kuala Lumpur, Malaysia.

Armstrong, K. (2000). Islam: A Short History. USA: Random House.

Al-Khasawneh, A. L., Al-Jammal, H.R. \& Al-Khasawneh, M. (2015). Human Resources Stature from the ISLAMIC Perspective: Deductive Analytical Study from Qur'an. International Journal of Academic Research in Business and Social Sciences, 5(12). 
Ajmal, M. B., \& Irfan, S. (2014). Understanding the Moderating Role of Islamic Work Ethics between Job Stress and Work Outcomes. Journal of Business and Management, 16(1), 62-67.

Ahmad, M. S. (2011). Work ethics: An Islamic prospective. International Journal of Human Sciences, 8(1), 850-859.

Ali, A. J., \& Al-Owaihan, A. (2008). Islamic work ethic: a critical review. Cross Cultural Management: An International Journal, 15(1), 5-19.

Ali, J.A. 1988. Scaling an Islamic work ethics. J. Social Psychology. 128(5): 575-583.

Ali, J.A. (2005). Islamic Perspectives on Management and Organization. Edward Elgar Publishing, UK.

Awan, K. Z., Abbas, M., Qureshi,I., \& Shahzad, K.(2014) Exploring the relationship between Islamic work ethics, employee work performance and the mediation role of organizational commitment. Journal of Asian development studies.3 (3),64-81.

Abbasi,A. S., \& Muneer, S. (2013). The impact of Islamic work ethics on employee performance: testing two models of personality X and personality Y. Science International (Lahore), 25(3), 611-617.

Bono, J. E., and T. A. Judge. 2003. "Core Self-Evaluations: A Review of the Trait and Its Role in Job Satisfaction and Job Performance.” European Journal of Personality 17: S5-S18. doi:10.1002/(ISSN)1099-0984.

Berings, D., De Fruyt, F., \& Bouwen, R. (2004). Work values and personality traits as predictors of enterprising and social vocational interests. Personality and Individual Differences, 36(2), 349-364.

Clary, E. G., Snyder, M., Ridge, R. D., Copeland, J., Stukas, A. A., Haugen, J., \& Miene, P. (1998). Understanding and assessing the motivations of volunteers: a functional approach. Journal of personality and social psychology, 74(6), 1516.

Din, M. U, \& Farooq, S. (2017). Effect of Islamic Work Ethics on Employee Well-Being, Job Stress and Turnover Intention. Sarhad Journal of Management Sciences, 2(02), 157-163.

Durrani, F. (2017). Mediating role of organizational justice in relationship between Islamic work ethics and employee turnover intention. Pakistan Journal of Commerce and Social Sciences (PJCSS), 11(3), 1050-1068.

Frey, B. S., \& Jegen, R. (2001). Motivation crowding theory. Journal of economic surveys, $15(5), 589-611$.

Furnham, A. (2005). The Psychology of Behavior at Work, The Individual in the Organization. New York: Psychology Press.

Gong, Y., Huang, J. C., \& Farh, J. L. (2009). Employee learning orientation, transformational leadership, and employee creativity: The mediating role of employee creative self -efficacy. Academy of Management Journal, 52(4), 765-778. 
Gilson, L. L., Mathieu, J. E., Shalley, C. E., \& Ruddy, T. M. (2005). Creativity and standardization: Complementary or conflicting drivers of team effectiveness? Academy of Management Journal, 48(3), 521-531.

Goodman, S. A., \& Svyantek, D. J. (1999). Person-organization fit and contextual performance: Do shared values matter. Journal of vocational behavior, 55(2), 254-275.

Hayati, K., \& Caniago, I. (2012). Islamic work ethic: The role of intrinsic motivation, job satisfaction, organizational commitment and job performance. Procedia-Social and Behavioral Sciences, 65, 1102-1106.

Isen, A. M. 2001. “An Influence of Positive Affect on Decision Making in Complex Situations: " Theoretical Issues With Practical Implications.” Journal of Consumer Psychology,11 (2): 75-85.doi:10.1207/S15327663JCP1102_01.

Janssen, O. (2000). Job demands, perceptions of effort-reward fairness and innovative work behavior. Journal of Occupational and Organizational Psychology, 73(3), 287-302.

Jex, SM 2002, Organizational Psychology: A Scientist-Practitioner Approach. John Wiley \& Sons, New York.

Kasser, T., and R. M. Ryan. 1996. "Further Examining the American Dream: Differential Correlates of Intrinsic and Extrinsic Goals.” Personality and Social Psychology Bulletin 22:280-287. doi:10.1177/0146167296223006.

Khalil, M., \& Abu-Saad, I. (2009). Islamic work ethic among Arab college students in Israel. Cross Cultural Management: An International Journal, 16(4), 333-346.

Khan, K., Abbas, M., Gul, A., \& Raja, U. (2015). Organizational justice and job outcomes: Moderating role of Islamic work ethic. Journal of Business Ethics, 126(2), 235-246.

Karatepe, O. M., \& Tekinkus, M. (2006). The effects of work-family conflict, emotional exhaustion, and intrinsic motivation on job outcomes of front-line employees. International Journal of Bank Marketing, 24(3), 173-193.

McClelland, D. 1961The achieving society. New Jersey: Van Nostrand.

Mohamed, N., Karim, N. S. A., \& Hussein, R. (2010). Linking Islamic work ethic to computer use ethics, job satisfaction and organizational commitment in Malaysia. Journal of Busines Systems, Governance and Ethics, 5(1), 13-23.

Murtaza, G., Abbas, M., Raja, U., Roques, O., Khalid, A., \& Mushtaq, R. (2014). Impact of Islamic work ethics on organizational citizenship behaviors and knowledge-sharing behaviors. Journal of Business Ethics, 133(2), 1-9.

Mohammad, J., \& Quoquab, F. (2016). Furthering the thought on Islamic work ethic: how does it differ? Journal of Islamic Marketing, 7(3), $355-375$.

Mohsan, F., Nawaz, M. M., Khan, M. S., Shaukat, Z., \& Aslam, N. (2011). Impact of customer satisfaction on customer loyalty and intentions to switch: Evidence from banking sector of Pakistan. International Journal of Business and Social Science, 2(16). 
Mundhra, W. C. D. (2010). Intrinsic motivational canvass in the Indian service sector: An empirical study. Vision, 14(4), 275-284.

Nithyanandan,D.V.(2010). Work Value as Motivation among software professionals. Management Prudence, 1(1), 23.

Oluseyi, S., \& Ayo, H. T. (2009). Influence of work motivation, leadership effectiveness and time management on employees' performance in some selected industries in Ibadan, Oyo State, Nigeria. European Journal of Economics, Finance and Administrative Sciences, 16(1), 7- 16.

Rahman, N. M. \& Muhammad, N. \& Othman, A S. (2006). The relationship between Islamic work ethics and organizational commitment: a case analysis. Malaysian Management Review, vol. 41, no.1, pp.

Roeand Ester, P. (1999). Values and work: Empirical findings and theoretical perspective. Applied psychology, 48(1), 1-21.

Rokhman, W. 2010. The Effect of Islamic Work Ethics on Work Outcomes. Electronic J. of Business Ethics and Organization Studies, 15 (1), 21-27.

Rehman, W., Zaman, H. F., \&. Haroon, M (2012). The relationship between Islamic work ethics and job satisfaction in healthcare sector of Pakistan. International Journal of Contemporary Business Studies, 3(5), 6-12.

Rokhman, W., \& Omar, A. (2008). The effect of Islamic work ethics on job satisfaction, organizational commitment and turnover intention: a study on Islamic microfinance institutions in Central Java, Indonesia. Jurnal Bisnis \& Manajement 4(1), 20-28.

Rawwas, M., Swaidan, Z., \& Isakson, H. (2013). A comparative study of ethical beliefs of master of business administration students in the United States with those in Hong Kong. Journal of Education for Business, 82(3), 146-158.

Rizk, R.R. (2008) "Back to basics: an Islamic perspective on business and work ethics", Social Responsibility Journal, Vol. 1/2, pp. 246-254.

Ryan, J. C., \& Tipu, S. A. (2016). An empirical alternative to Sidani and Thornberry's (2009)'current Arab work ethic': examining the multidimensional work ethic profile in an Arab context. Journal of business ethics, 135(1), 177-198.

Ryan, R., and L. Deci. 2000. "Intrinsic and Extrinsic Motivations: Classic Definitions and New.

Directions." Contemporary Educational Psychology 25: 54-67. doi:10.1006/ceps.1999.1020.

Simon, M. (2008). The Protestant Work Ehics (PWE) revisited: a promising concept or an outdated idea? Social Science Research Center Berlin, 1-22.

Salahudin, S.N., Baharuddin, S.S.B., Abdullah, M.S. \& Osman, A. (2016). The Effect of Islamic Work Ethics on Organizational Commitment. Procedia Economics and Finance, 35, $582-590$. 
Sadaozai, A.M., Marri, M.Y.K., Zaman, H.M.F., Yousafzai, M.I., \& Nas, Z.(2013). Moderating role of Islamic work ethics between the relationship of organizational commitment and turnover intentions: A study of public sector of Pakistan. Mediterranean journal of social sciences,4(2), 767

Vallerand, R. J. 1997. Toward a hierarchical model of intrinsic and extrinsic motivation. Adv. Experiment. Soc. Psych. 29, 271-360.

William, S., J. Weinman, and J. Dale. 1998. "Doctor-Patient Communication and Patient Satisfaction: A Review.” Family Practice 15: 480-492. doi:10.1093/fampra/15.5.480.

Yousef, D. A. (2000a). Organizational commitment as a mediator of the relationship between Islamic work ethic and attitudes toward organizational change. Human Relations, 53, 513537.

Yousef, D. A. (2001). Islamic Work Ethic A Moderator between Organizational Commitment and Job Satisfaction in A Cross-Cultural Context. Personnel Review, Vol. 30, No. 2, 2001, pp. 152-169.

Zahrah, N. (2016). The Relationship between Islamic Religiosity, Islamic Work Ethics and Job Performance. The European Proceedings of Social \& Behavioral Sciences, 710-16.

Zaman, F., Nas, Z., Ahmad, M., Raja, Y.M., Mari., M.Y.(2013) The mediating role of intrinsic motivation between Islamic work ethics and employee job satisfaction. Journal of business studies quarterly, 5(1), 93-102. 